\title{
Augustine's view of Manichaean almsgiving and almsgiving by the Manichaean community at Kellis
}

\begin{tabular}{|c|c|}
\hline \multicolumn{2}{|c|}{$\begin{array}{l}\text { Author: } \\
\text { Majella Franzmann }{ }^{1,2}\end{array}$} \\
\hline \multicolumn{2}{|c|}{$\begin{array}{l}\text { Affiliations: } \\
{ }^{1} \text { Faculty of Humanities, } \\
\text { Curtin University, Australia }\end{array}$} \\
\hline \multicolumn{2}{|c|}{$\begin{array}{l}{ }^{2} \text { Research Colleague, } \\
\text { Department of Church } \\
\text { History and Polity, University } \\
\text { of Pretoria, South Africa }\end{array}$} \\
\hline \multicolumn{2}{|c|}{$\begin{array}{l}\text { Note: } \\
\text { Contribution to 'Augustine } \\
\text { and Manichaean } \\
\text { Christianity', the First } \\
\text { South African Symposium } \\
\text { on Augustine of Hippo, } \\
\text { University of Pretoria, } \\
\text { 24-26 April 2012. Dr Majella } \\
\text { Franzmann is participating as } \\
\text { research colleague of Prof. } \\
\text { Dr Hans van Oort, Professor } \\
\text { Extraordinarius, Department } \\
\text { of Church History and Polity } \\
\text { of the Faculty of Theology, } \\
\text { University of Pretoria, } \\
\text { Pretoria, South Africa. }\end{array}$} \\
\hline \multicolumn{2}{|c|}{$\begin{array}{l}\text { Article republished } \\
\text { with updated side bar } \\
\text { information. }\end{array}$} \\
\hline \multicolumn{2}{|c|}{$\begin{array}{l}\text { Correspondence to: } \\
\text { Majella Franzmann }\end{array}$} \\
\hline \multicolumn{2}{|c|}{$\begin{array}{l}\text { Email: } \\
\text { m.franzmann@curtin.edu.au }\end{array}$} \\
\hline \multicolumn{2}{|c|}{$\begin{array}{l}\text { Postal address: } \\
\text { PVC Humanities Office, } \\
\text { Curtin University, GPO Box } \\
\text { U1987, Perth WA 6845, } \\
\text { Australia }\end{array}$} \\
\hline \multicolumn{2}{|c|}{$\begin{array}{l}\text { Dates: } \\
\text { Received: } 02 \text { Nov. } 2012 \\
\text { Accepted: } 10 \text { Jan. } 2013 \\
\text { Published: } 10 \text { Apr. } 2013 \\
\text { Republished: } 08 \text { Nov. } 2013\end{array}$} \\
\hline \multicolumn{2}{|c|}{$\begin{array}{l}\text { How to cite this article: } \\
\text { Franzmann, M., 2013, } \\
\text { 'Augustine's view of } \\
\text { Manichaean almsgiving } \\
\text { and almsgiving by the } \\
\text { Manichaean community } \\
\text { at Kellis', HTS Teologiese } \\
\text { Studies/Theological Studies } \\
69(1), \text { Art. \#1356, } 5 \text { pages. } \\
\text { http://dx.doi.org/10.4102/ } \\
\text { hts.v69i1.1356 }\end{array}$} \\
\hline \multicolumn{2}{|l|}{ Read online: } \\
\hline 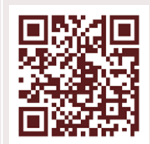 & $\begin{array}{l}\text { Scan this QR } \\
\text { code with your } \\
\text { smart phone or } \\
\text { mobile device } \\
\text { to read online. }\end{array}$ \\
\hline
\end{tabular}

Taking its point of departure from Augustine's criticism of Manichaean practices with food and drink that appear to disregard the New Testament injunction to give to the poor, or to those who are hungry and thirsty, this article investigates the probability that this was indeed Manichaean practice, by interrogating Manichaean texts and clues about Manichaean practice contained in the personal letters from 4th century CE Roman Kellis in Egypt. A further consideration of types of exclusive communities and their behaviour, or exclusive behaviour at various times from groups that are generally characterised as inclusive, leads to the proposal that Manichaean exclusivity was based firmly on an underlying theology and narrative myth of cosmic salvation that fixed an unalterable Manichaean community practice, carried out in a wide range of geographical locations and historical times.

\section{Introduction}

Three texts bear witness to Augustine's negative views about Manichaean almsgiving in relation to food - De moribus manichaeorum 36, ${ }^{1}$ Contra Faustum 15.7, ${ }^{2}$ and Confessionum libri XIII 3.10.18. ${ }^{3}$ The texts also provide the reasons for his disapproval: Manichaeans give food and drink only to their own rather than to those in need, because to give to non-Manichaeans would be to imprison further in the darkness the 'limb of God' (Light/Soul), which is already trapped within food matter and water. In Contra Faustum he pursues the point further. Refusing food alms to those in need by following the law laid down by Mani is to break the commandment laid down by God, 'You shall not kill' (Ex 20:13; Dt 5:17):

From fear of fancied murder, thou dost actually commit murder. For if thou wast to meet a beggar starving for want of food, by the law of God to refuse him food would be murder; while to give food would be murder by the law of Manichæus. (Contra Faustum)

Augustine's own experience as a Manichaean Hearer involved in food practices with the community is also documented with regret and negativity in the Confessions 4.1.1 (and also possibly 3.6.10) as is his enjoyment of the hospitality they offered him as he recovered from his illness, no doubt also including food hospitality (Confessionum libri XIII, 5,10.18). ${ }^{4}$

In what follows I outline from Manichaean texts the Manichaean concept of almsgiving as it relates to the activity of releasing the 'limb of God', and then investigate what evidence we have for that activity at ancient Kellis. I will also look briefly at how we might characterise or account for such exclusionary practices from a marginal socio-religious group within the Roman world.

\section{The Manichaean concept of almsgiving}

Jason BeDuhn brings together the three texts cited from Augustine on almsgiving of food and drink in his work on The Manichaean Body within a discussion of the redemption of the Light/ Soul. That redemption is accomplished in part by releasing the light in the activity of eating undertaken by the Elect. Giving food to non-Manichaeans amounts to re-imprisonment of the Light/Soul since they are incapable of releasing the light (BeDuhn 2000:171, 316, n. 24).

It would seem imperative that exclusive practices with food be adhered to, given the Manichaean belief in the necessity of liberating the light. However we know also that the Manichaeans

1.'That is why you forbid anyone to give bread, vegetables, or even water ... to a beggar if he is not a Manichaean, for fear that the limb of God which is mixed with these things will be defiled by his sins and thus be hindered in its return.'

2.'You do not give bread to the hungry, from fear of imprisoning in flesh the limb of your God.'

3.'And I, miserable one, believed that more mercy was to be shown to the fruits of the earth than unto men, for whom they were created; for if a hungry man - who was not a Manichæan - should beg for any, that morsel which should be given him would appear, as it were, condemned to capital punishment.'

4.My thanks to Jacob Albert van den Berg for his discussion with me about Augustine's own experience in this regard and other matters in this article. 
followed the canonical gospels, quoting liberally from them throughout the Western writings, and that Mani appears to have considered himself an Apostle of Jesus Christ, often quoting from sayings of Jesus as 'the Saviour' (Franzmann 2003:15-26). How then does one make sense of such an exclusivist practice with food in relation to the needy when there appear to be clear injunctions to do otherwise, for example, Matthew 25:31-46?

I will not rehearse here what I have written elsewhere in detail about the concepts of poverty and treasure in Manichaean texts, but simply offer a summary of the Manichaean attitude to the needy and almsgiving (Franzmann 2011:235-243). Whilst Manichaean texts refer to the poor or the needy more often in a spiritual than a socio-economic sense, Manichaean theology about, and the practice of almsgiving, bring together both the spiritual and the literal sense of the needy/poor. The Elect are the poor, who rely for their subsistence on the alms given by catechumens, whether that be food or clothing or some other material goods. The Elect in turn are exhorted not to take more than they need so as to remain in poverty, which is the foundation of their bliss (13941=T II K \& 14285=T II D. 136, in Klimkeit 1993:203). Whilst almsgiving to the Elect involves depriving oneself of physical goods, catechumens are urged to gain spiritual riches by this activity (Kephalaia 229.4-10; Gardner 1995). The food the Elect receive as alms from the catechumens (Kephalaia 208.27-29), is consumed in order to purify it and release the light trapped in the darkness of the material world (Kephalaia 217.11-16).

Whilst these are injunctions in a positive sense as to where the catechumen should direct alms, I have found no injunction about where not to direct alms. I have identified in my earlier work a saying regarding unworthy eating in the Sogdian homily on the correct preparations for the sacred meal, M 139 II: 'For everyone who partakes of the meal and is not worthy of it loses the fruit of his great efforts and is shut out of the Paradise of Light' (in Klimkeit 1993:151). One could consider extrapolating from this saying to an injunction regarding food alms to those who are unworthy, however the saying is focused on the loss of personal salvation to the person who eats unworthily rather than the effect that eating unworthily has on the Light itself.

\section{Manichaean almsgiving at Kellis}

The Coptic and Greek letters found on the Dakhleh Oasis in the 4th century CE Egyptian Roman town of Kellis give a good insight into the everyday life and concerns of the community (Gardner, Alcock \& Funk 1999; Worp, Whitehorne \& Daniel 1995). In particular we gain a very good idea of the life of the women of the community, and the roles they played on the oasis whilst the men were absent on business. They are the principal sources for our knowledge of almsgiving in that community and interestingly in this particular situation of almsgiving, their business and spiritual lives go hand in hand. Apart from or together with what might be inherited, business is one way of acquiring resources so that alms can be given.
There is not space in this present work to deal in detail with resources gained by the women whose lives are set before us in the Kellis letters, either through inheritance or business. Suffice it to say that there are women on the oasis who have the wherewithal to give alms, as is clear both from letter writers who ask them for alms, and from the letters of the women themselves detailing their almsgiving. Whilst the women carry out some financial activity on behalf of their menfolk, it is also clear that they have resources in their own right. The business accounts, P. Kell. Copt. 44-50 (Gardner et al. 1999), that appear to relate to the weaving business of the woman named Tehat, are evidence of this..$^{5}$ They show that Tehat is an active and successful businesswoman. She pays wages, employs workers and oversees their work, negotiates business and profits with a male partner, and perhaps also runs a camel freight business. P. Kell. Copt 32 and 33 give evidence of a similar occupation of weaving or tailoring for the female catechumen, Eirene. ${ }^{6}$ The same occupations are shared by other women on the oasis.

The Kellis documents indicate that women are clearly very active in legal and financial matters in the community, owning property and goods, buying and selling goods and their own labour, lending and borrowing money. Whilst apart from a few cases, none of the women appear to be rich, and the financial and legal activity is limited to the village or to the oasis area, the women are nevertheless fully and actively involved. Some of these women are, like Tehat and Eirene, Manichaeans. They and other women like them are generous with the fruits of their business. As to who benefits from the generosity of the Manichaean women, there are requests and subsequent gifts to those we presume are the Elect. These gifts include both clothes and food. P. Kell. Copt. 31 is from an anonymous writer to a group of anonymous Manichaean women, presumably in Kellis. The letter praises their piety (they are 'helpers, and worthy patrons, and firm unbending pillars ...') and asks for oil. Similarly, the begging letter sent to Eirene, P. Kell. Copt. 32, praises her spiritual riches and asks for alms (see Gardner et al. 1999).

We must include here too those women who give an agape, although there is still some question as to whether that is simply an almsgiving out of charity/love, or food for the sacred meal. ${ }^{7}$ Theodora is mentioned as the giver of agape: a maje of olives and a half maje of grapes (P. Kell. Copt 44). From P. Kell. Copt. 47, we learn that Tehat gives an agape of lentils and lupin seeds.

Apart from these there are other gifts. In P. Kell. Copt. 18, Horion includes tailoring instructions for a cowl as well as weaving instructions for a cowl for a double-fringed gown for a presbyter. Perhaps this clothing is an alms gift as well. In P. Kell. Copt. 33, we learn that Eirene is making garments for the male elect who writes to her.

5.For a more detailed work on Tehat, see Franzmann (2007:17-26).

6.Gardner et al. (1999:24) questions whether this is an actual name or whether it is the salutation 'peace'. If it is not Eirene, what is said here refers to a female believer of the community. For a more detailed study of Eirene, see Franzmann (2006:153-162).

7.Anthony Alcock (2000:208) interprets this agape as a reference to the celebration of the Manichaean sacred meal similar to the Christian agape. 
In P. Kell. Copt. 43, Tehat urges her son to do charitable deeds for some orphans, giving them baked loaves but also perhaps pots of something else. The recipients are simply referred to as 'orphans' and there is no way of knowing whether these belong to the Manichaean community or not.

The women left behind on the oasis must have, by necessity become those who held the community together in a very practical way whilst their menfolk were away on business. Eirene and Tehat are typical of the women in this close community - good business women and firm believers. Whilst we have one reference to a male - Tehat's son is encouraged to give alms - it is the women who figure prominently as almsgivers in the texts.

We need to be clear here that we are concerned with food alms, not all almsgiving. As to other types of almsgiving, including clothing, we have no evidence of injunctions to give exclusively to Manichaeans. Although there is some doubt that in the Kellis community almsgiving was completely exclusive, the majority of cases documented appear to bear out the truth of Augustine's statements. However, the one clear difference we have noted with the alms for the orphans relates to food, and thus this text remains problematical.

\section{Exclusive communities and food exclusion}

Exclusivism in communities at various times of their development is not rare, even for Christian communities who purport to follow the inclusive practice and theological viewpoint of the founder. Thus in Hippolytus's (3rd century CE) Commentary on Daniel 4.38.2, we find the argument that those who have acquired the power of the spirit should not help someone in any way who does not have this power of the spirit (Bardy \& Lefèvre 1947:204). Whilst the passage is in reference to Daniel as the only one to receive a vision (Dn 10:7) and thus may refer to a person's ability to have visions only if they are amongst the saints and those who fear Christ, it may also be a general statement about any assistance from members of the community to those outside. For an example of exclusivism centred on food, however, one need look no further than Acts 6:1 with the disputes over the distribution of food to the needy (widows) in the early Jerusalem community, which differs so much from the first narrative about a community owning all things in common (Ac 4:32). Interestingly the lines of exclusivism here are drawn between two ethnic groups, the Hellenists (Greek-speaking Jews) and the Hebrews (Aramaic-speaking Jews). Whilst not an example of absolute exclusivism, Galatians 6:10 shows a community whose preference is for doing good, especially to their own.

Whilst we might agree that there are good theological reasons for Manichaeans not providing food alms to nonManichaeans, we should also look deeper for the basis for such a theological viewpoint within the larger mythology. If we go back to the example of Hippolytus and consider the time in which he writes and the relatively early phase of development of Christian communities in which he was living - characterised by sporadic persecution but also a degree of social and political discrimination - one is not surprised by a viewpoint that is somewhat akin to that found in many Gnostic texts, that the community is made of those whose homeland is above and who are gathered ghetto-like as a party of foreigners within this world.

However, even in our own time exclusivist groups do not always deny charity to others. Whilst the Exclusive Brethren withdraw from the world so as not to be polluted by it, and do a great deal of charitable giving but only within the group, the old order Mennonites all do philanthropy outside the group. Moreover, one cannot put down exclusive giving necessarily to a lack of resources to do more outside a group. ${ }^{8}$ The Exclusive Brethren, for example, run extremely successful small-to-medium businesses and use the tax and welfare systems adroitly to maximise their incomes, so there is no lack of resource if the group wished to give more widely in the community.

The exclusivity of the Manichaeans is based on a repudiation of the world that entraps the light in its darkness. One entraps the light further by giving food alms to non-Manichaeans. On the other hand, one enables the release of the light by giving food alms for the agape (e.g. P. Kell. Copt. 47), promoting the unity of the community over against the world and the darkness by the simple action of sharing food together. How are we to understand such exclusive behaviour that draws the community together against the world? As far as I can ascertain, social scientists have not yet provided us with a typology of exclusive groups, but there has been work by anthropologists on the features of ethnic groups and how they interact within larger social settings, that might prove helpful for us. The work of Fredrik Barth (1968) is particularly apposite in providing parallels with Manichaean groups:

When defined as an ascriptive and exclusive group, the nature of continuity of ethnic units is clear: it depends on the maintenance of a boundary. The cultural features that signal the boundary may change, and the cultural characteristics of the members may likewise be transformed, indeed, even the organizational form of the group may change - yet the fact of continuing dichotomization between members and outsiders allows us to specify the nature of continuity, and investigate the changing cultural form and content. (p. 15)

Of course the idea of group boundaries and related ideas about, or group practices with, food can be found in the work of the anthropologist Mary Douglas. Many years ago I used her work as the basis for a study of the New Testament Jesus and the symbols of food and body that underpinned his inclusive view of the reign of God (Franzmann 1992:17-31). It seems now that the negative side of that theory could be used to good effect when studying the Manichaean attitude to food and food alms. For Douglas, body imagery used by a

8.See Bachelard (2009); Kraybill (2001). My thanks to Prof Marion Maddox (Macquarie University Sydney), for her helpful discussion of contemporary exclusivist religious groups. 
particular culture, or cultural subset, reflects social order. The treatment of bodily orifices/margins in particular is of great significance since they symbolise potential vulnerability for that social order. Where political or physical boundaries are at risk from others, whatever comes from body orifices, and thus moves across the body boundary, can be the source of great risk and needs to be dealt with as a priority (Douglas 1970:121):

Interest in its [the body's] apertures depends on the preoccupation with social exits and entrances, escape routes and intrusions. If social boundaries have no meaning, I would not expect to find concern with bodily boundaries ... (Douglas 1969:69-80, esp. 71).

Since food enters and leaves the body by way of its orifices, food imagery is thus intimately connected with body imagery, and especially imagery to do with body margins. Thus if body margins/orifices are of high importance for the structuring imagery of a society, food will be also by corollary (Douglas 1970:126-127).

Of course I am not suggesting that there are strong and exact parallels between the ancient Jewish dietary laws that were the focus of Douglas' study, and the ideas around food and exclusion in Manichaeism, but this kind of anthropological theory could be used to advance our understanding of Manichaean practices regarding food. Such a study would build on Jason BeDuhn's work on the Manichaean body. BeDuhn (2000) writes of the Manichaean prohibition of food alms to the poor in terms of an overwhelming concern for body margins, and the pollution experienced in transgressing those margins first and foremost through sexual intercourse:

... Manichaean food-economy is not about charity or the cultivation of commensality. Alms within the Manichaean community are literally korban, set aside for the altar of sacrifice and forbidden to profane consumption.

The sins of the non-Manichaean which threaten to defile the divine substance in food include, first and foremost, sexual intercourse, which congeals the substance into a soul locked into a new body... (p. 171)

Perhaps together with such a study, it would be helpful to consider Mani's life from an early age, first within a predominantly female family setting and thereafter in a very different setting within the Elchaisites, and how this may have affected the construction of a myth system that supported such behaviours. What were the physical and emotional stress points in the changes Mani experienced from one environment to the other and the implicit and explicit 'conversion' messages from his father that enabled the transition?

\section{Conclusion}

There is much that would still lend itself to fruitful enquiry in relation to the Manichaean practice with food alms. I have limited the discussion of that activity to the general setting that Augustine would have known - Manichaeans in the 3rd/4th century Roman world, rather than the full range of Manichaean communities that eventually stretched as far east as China.
Let me return finally to those 3rd/4th century Manichaean women at Kellis. What might such a practice with food alms mean to the women, and what might this demand of them within a small town setting? A small community expects and supports behaviours that are different from those in a large town, so I would suggest that the way of life of the Manichaean women at Kellis might be somewhat different from Manichaean women in Alexandria, for example. Moreover, how might the Manichaeism that came to Kellis have been changed in the actual lived experience there? What Barth (1968) writes of 'the effects of ecology' on ethnic groups, might also be true of the Manichaeans at Kellis:

The overt cultural forms which can be itemized as traits exhibit the effects of ecology. By this I do not mean to refer to the fact that they reflect a history of adaptation to environment; in a more immediate way they also reflect the external circumstances to which actors must accommodate themselves. The same group of people, with unchanged values and ideas, would surely pursue different patterns of life and institutionalize different forms of behaviour when faced with the different opportunities offered in different environments? (p. 12)

In small towns, everyone is needed to keep the town going and working. Would all those at Kellis be expected to give to the needy? What might happen if Manichaeans were not seen to be doing their civic duty? If these Manichaean women were converts, and thus had not always lived as Manichaeans, would they be able to turn away from members of their former families if they were in need of food? Whilst almost every instance of their almsgiving appears to refer to gifts to the Elect or for the sacred meal, we are still left with the case of the orphans who receive food alms. Is it conceivable that these orphans were non-Manichaean kin or friends or townsfolk in trouble who could not be ignored and to whom alms were given? What texts say, and what happens in everyday life, may not quite be the same in all cases. Perhaps Augustine was not completely right in every case.

\section{Acknowledgements Competing interests}

The author declares that she has no financial or personal relationship(s) which may have inappropriately influenced her in writing this article.

\section{References}

Alcock, A., 2000, 'The Agape', Vigiliae Christianae 54, 208-209. http://dx.doi.org/ $10.1163 / 157007200 \times 00053$

Augustinus 1979, 'Confessionum libri XIII', in P. Schaff (ed.), The Confessions and Letters of St. Augustin, with a Sketch of his Life and Work, pp. 190-207, Eerdmans, Grand Rapids, MI. (Nicene and Post-Nicene Fathers 1).

Augustinus, 1984a, 'Contra Faustum', in P. Schaff (ed.), St. Augustin: The writings against the Manichaeans and against the Donatists, pp. 264-592, Eerdmans, Grand Rapids, MI. (Nicene and Post-Nicene Fathers 4).

Augustinus, 1984b, 'De moribus manichaeorum', in P. Schaff (ed.), St. Augustin: The writings against the Manichaeans and against the Donatists, pp. 113-157, Eerdmans, Grand Rapids, MI. (Nicene and Post-Nicene Fathers 4).

Bachelard, M., 2009, Behind the exclusive brethren, Scribe Publications, Melbourne.

Bardy, G. \& LeFèvre, M., 1947, Commentaire sur Daniel: Texte établi et traduit, Sources chrétiennes, Éditions du Cerf, Paris. PMid:18906535

Barth, F., 1968, 'Introduction', in F. Barth (ed.), Ethnic groups and boundaries: The social organization of culture difference, pp. 9-37, Waveland Press, Long Grove.

BeDuhn, J.D., 2000, The Manichaean body in discipline and ritual, Johns Hopkins University Press, Baltimore. 
Douglas, M., 1969, 'Social preconditions of enthusiasm and heterodoxy', in R.F. Spencer (ed.), Forms of symbolic action: Proceedings of the 1969 Annual Spring Meeting of the American Ethnological Society, American Ethnological Society, Seattle, United the American Ethnolo
States, pp. 69-80.

Douglas, M., 1970, Purity and danger: An analysis of concepts of pollution and taboo, Penguin, London.

Franzmann, M., 1992, 'Of food, bodies, and the boundless reign of God', Pacifica 5, 17-31.

Franzmann, M., 2003, Jesus in the Manichaean writings, T\&T Clark International, Edinburgh. PMCid:403754

Franzmann, M., 2006, 'An "heretical" use of the New Testament: A Manichaean adaptation of Matt 6:19-20 in P. Kell. Copt. 32', in C. Breytenbach, J. Thom \& J. Punt (eds.), The New Testament Interpreted: Essays in Honour of Bernard C. Lategan, pp. 153-162, Brill, Leiden. (Novum Testamentum suppl. 124).

Franzmann, M., 2007, 'Tehat the Weaver: Women's experience in Manichaeism in 4th century Roman Kellis', Australian Religion Studies Review 20(1), 17-26. http:// dx.doi.org/10.1558/arsr.v20i1.17
Franzmann, M., 2011, 'The treasure of the Manichaean spiritual life', in J.A. van den Berg, A. Kotzé, T. Nicklas \& M. Scopello (eds.), Augustine, Manichaeism and Gnosticism: Studies for Johannes van Oort at sixty, pp. 235-243, Brill ej.9789004189973.i-730.67
Leiden. (Nag Hamman Studies 74). http://dx.doi.org/10.1163/

Gardner, I.M.F. (ed.), 1995, The Kephalaia of the Teacher: The edited Coptic Manichaean texts in translation with commentary, E.J. Brill, Leiden. (Nag Hammadi and Manichaean Studies 37).

Gardner, I.M.F., Alcock, A. \& Funk, W-P. (eds.), 1999, Coptic documentary texts from Kellis, vol. 1, P. Kell. V (P. Kell. Copt. 10-52; O. Kell. Copt. 1-2), Oxbow Books, Oxford. (Dakhleh Oasis Project Monograph ser. 5).

Klimkeit, H-J., 1993, Gnosis on the Silk Road: Gnostic texts from Central Asia, Harper Collins, New York.

Kraybill, D.B., 2001, The riddle of Amish culture, (rev. edn.), The Johns Hopkins University Press, Baltimore. PMCid:2408368

Worp, K., Whitehorne, J.E.G. \& Daniel, R.W. (eds.), 1995, Greek Papyri from Kellis. (P.Kell.G.), Nos. 1-90, Oxbow Books, Oxford. (Dakhleh Oasis Project Monograph 3/Oxbow Monograph 54) 